\title{
Aktivitas Gel Ekstrak Etanol Daun Pucuk Merah (Syzygium myrtifolium) Terhadap Penyembuhan Luka Bakar Tikus Sprague-dawley
}

\author{
Lusi Indriani*, Almasyhuri, Aldryan Racka Pratama \\ Program Studi Farmasi, Universitas Pakuan, \\ Bogor, Jawa Barat, Indonesia 16134 \\ *Email Korespondensi : lusi.indriani@unpak.ac.id
}

\begin{abstract}
ABSTRAK
Luka bakar adalah bentuk kerusakan jaringan yang disebabkan kontak dengan sumber panas seperti api, air panas, bahan kimia, listrik, dan radiasi. Gejalanya berupa sakit, bengkak, merah, melepuh karena permeabilitas pembuluh darah meningkat. Salah satu tanaman yang diduga berpotensi sebagai obat luka bakar adalah daun pucuk merah (Syzygium myrtifolium), yang mengandung beberapa senyawa metabolit sekunder seperti alkaloid, flavonoid, kalkon, tanin, dan terpenoid. Penelitian ini bertujuan untuk mengetahui aktivitas gel ekstrak etanol daun pucuk merah pada luka bakar tikus putih jantan Sprague-Dawley. Kelompok perlakuan terdiri dari formula 1 (ekstrak daun pucuk merah 2\%), formula 2 (ekstrak daun pucuk merah $4 \%$ ), formula 3 (ekstrak daun pucuk merah 6\%), Bioplacenton sebagai kontrol positif dan basis gel sebagai kontrol negatif. Hasil penelitian menunjukkan bahwa gel ekstrak daun pucuk merah memberikan efek sebagai obat luka bakar, dimana proses penyembuhan ditandai dengan penurunan diameter luka yang lebih cepat pada tikus. Formula 3 menunjukkan persentase penyembuhan luka bakar yang paling efektif yaitu 99,81\% sembuh setelah 17 hari.
\end{abstract}

Kata Kunci : Luka bakar; gel; daun pucuk merah

\section{Burned Wound Healing Activity Of Syzygium myrtifolium Leaves Ethanol Extract Gel}

\begin{abstract}
Burned wound is a form of tissue damage caused by skin contact with heat sources such as fire, hot water, chemicals, electricity, and radiation. The symptoms include pain, swelling, redness, blistering due to increased vascular permeability. One of the plants suspected as a potential medicinal burn is Syzygium myrtifolium, which contains several secondary metabolites such as alkaloids, flavonoids, chalcons, tannin and terpenoids. This study aimed to determine the gel activity of ethanol extract of Syzygium myrtifolium leaves in Sprague-Dawley male white rats with burned wounds. The treatment groups consisted of gel formula 1 (2\% of Syzygium myrtifolium leaves extract), formula 2 (4\% of Syzygium myrtifolium leaves extract), formula 3 (6\% Syzygium myrtifolium leaves extract), bioplacenton as a positive control and gel base as a negative control. The results showed that the Syzygium myrtifolium extract gel provides the effect of burned wound healing. The healing process was marked by a rapid reduction in wound diameter in rats. The formula
\end{abstract}


three proved to be most effective burned wound healing gel with $99.81 \%$ of recover area after 17 days of healing time.

Keywords: Burned wound, Gel, Syzygium myrtifolium leaves

\section{PENDAHULUAN}

Luka bakar termasuk kecelakaan yang sering terjadi dalam kehidupan sehari-hari. Luka bakar adalah bentuk kerusakan jaringan yang disebabkan kontak dengan sumber panas seperti api, air panas, bahan kimia, listrik, dan radiasi. Gejalanya berupa sakit, bengkak, merah, melepuh karena permeabilitas pembuluh darah meningkat. Luka bakar dalam penyembuhannya lebih lambat, lebih sulit diobati, dan lebih rentan terhadap komplikasi seperti infeksi (Hasyim et al., 2012).

Salah satu tanaman yang diduga berpotensi sebagai obat luka bakar adalah daun pucuk merah. Penelitian mengenai daun pucuk merah antara lain bahwa ekstrak daun pucuk merah hasil maserasi dan sokletasi memiliki kandungan alkaloid, flavonoid, tanin dan saponin. Ekstrak tersebut memiliki aktivitas antidiare paling efektif pada dosis $7,72 \mathrm{mg} / 20 \mathrm{gBB}$ pada mencit putih jantan (Moerfiah et al., 2019). Hasil penelitian (Haryati et al., 2016) menunjukkan bahwa ekstrak etanol 96\% daun pucuk merah pada konsentrasi 2\% memiliki aktifitas antibakteri terhadap bakteri Staphylococcus aureus dengan diameter daerah hambat $8,20 \mathrm{~mm}$ dan terhadap bakteri Escherichia coli yaitu 8,70 $\mathrm{mm}$. Infeksi bakteri dapat memperlambat penyembuhan dengan memperpanjang fase inflamasi, dan memproduksi zat kimia serta enzim yang dapat merusak jaringan (DeLaune \& Ladner, 2002). Penelitian ini bertujuan untuk mengetahui aktivitas gel ekstrak etanol daun pucuk merah pada luka bakar tikus putih jantan Sprague-Dawley.

\section{METODE PENELITIAN}

\section{Alat dan Bahan}

Alat-alat yang digunakan adalah blender $\left(\right.$ Maspion $\left.^{\circledR}\right)$, timbangan analitik $\left(A n d^{\circledR}\right), \mathrm{pH}$ meter, oven $\left(\right.$ Memmert $\left.^{\circledR}\right)$, kertas saring, rotary evaporator $\left(B U C H I^{\circledR}\right)$, waterbath, alat-alat gelas $\left(\right.$ Pyrex $\left.{ }^{\circledR}\right)$, ayakan Mesh 40, alat pemanas, sarung tangan $\left(\right.$ Sensi $\left.^{(B)}\right)$ masker $\left(\right.$ Sensi $\left.^{(B)}\right)$, pot salep, kandang hewan uji, lumpang dan alu, pencukur bulu (Gillette $\left.{ }^{\circledR}\right)$, viskometer Brookfield, dan jangka sorong.

Bahan-bahan yang digunakan adalah daun pucuk merah, aquades, eter, etanol $96 \%$, etanol 70\%, Na-CMC, gliserin, propilenglikol, Bioplacenton ${ }^{\circledR}$, Ketamine $^{\circledR}$ injeksi, Xylazine ${ }^{\circledR}$ injeksi, Ketorolac $^{\circledR}$ injeksi, tikus putih jantan galur SpragueDawley 20 ekor dengan bobot 180-250 g berumur 3 bulan, pakan pellet dengan tipe BR 512.

\section{Pembuatan Simplisia dan Ekstrak Daun Pucuk Merah}

Hasil determinasi tanaman menyatakan bahwa tanaman yang digunakan dalam penelitian ini adalah pucuk merah (Syzygium myrtifolium Walp.) yang termasuk ke dalam suku Myrtaceae. Bagian yang digunakan adalah daun pucuk merah urutan p1-5 yang dihitung dari pucuk. Daun pucuk merah dikumpulkan sebanyak $3,2 \mathrm{~kg}$ selanjutnya disortasi basah untuk membersihkan daun dari pengotor seperti bagian daun yang sudah tua bersama tangkainya, atau bagian lain yang tidak termasuk dalam deskripsi. Kemudian dilakukan pencucian, dan dikeringkan menggunakan oven pada suhu $50-60^{\circ} \mathrm{C}$. Simplisia disortasi kembali dari pengotor yang tidak memenuhi syarat seperti bagian daun yang hangus atau belum cukup kering, selanjutnya simplisia dihaluskan menggunakan grinder dan diayak menggunakan ayakan Mesh 40 (DepKes, 2001). Ekstraksi dilakukan dengan metode maserasi menggunakan etanol 96\%. Sebanyak $500 \mathrm{~g}$ simplisia serbuk direndam dengan etanol $96 \%$ sebanyak $6 \mathrm{~L}$ yang dibagi untuk tiga kali maserasi. Dimana setiap proses maserasi dilakukan selama 24 
jam hingga diperoleh filtrat. Ketiga filtrat dikumpulkan dan diuapkan pelarutnya menggunakan rotary evaporator, kemudian dikentalkan diatas waterbath.

\section{Pembuatan dan Evaluasi Sediaan Gel}

Formula sediaan gel dibuat menggunakan basis Na-CMC (Maswadeh et al., 2006). Formula sediaan gel dengan variasi konsentrasi ekstrak dibuat mulai dari $2 \%$, 4\% hingga 6\% sebanyak $100 \mathrm{~g}$. Komposisi formula dapat dilihat pada Tabel 1. Larutan Na-CMC 0,5\% dibuat dengan cara $0,5 \mathrm{~g}$ serbuk Na-CMC ditabur pada 10 $\mathrm{mL}$ air panas kemudian dibiarkan selama kurang lebih 15 menit hingga berwarna bening dan berbentuk menyerupai gel. Selanjutnya diaduk hingga menjadi massa yang homogen dan diencerkan dalam labu ukur dengan aquades hingga volume 100 ml. Untuk membuat konsentrasi 2\%, sebanyak $2 \mathrm{~g}$ ekstrak dilarutkan dalam sebagian air kemudian dipanaskan pada suhu $50^{\circ} \mathrm{C}$. Ditambahkan 3 g larutan $\mathrm{Na}-$ CMC dan diaduk hingga homogen. Kemudian ditambahkan gliserin, propilenglikol dan sisa aquades hingga 100 $\mathrm{g}$ dengan pengadukan secara kontinyu hingga terbentuk sediaan gel (Maswadeh et al., 2006). Prosedur yang sama juga dilakukan pada ekstrak dengan konsentrasi $4 \%$ dan $6 \%$. Selanjutnya sediaan gel dilakukan pengujian organoleptik, $\mathrm{pH}$, homogenitas. viskositas dan daya alir.

\section{Pengujian Penyembuhan Luka Bakar}

Penelitian ini menggunakan hewan coba yaitu tikus jantan Sprague-Dawley sebanyak 20 ekor. Protokol penelitian telah mendapat persetujuan dari Komite Etik Penggunaan Hewan Percobaan Fakultas Matematika dan Ilmu Pengetahuan Alam Universitas Pakuan dengan Surat Keputusan No. 11/KEPHP-UNPAK/12-2018. Pengujian efek penyembuhan luka bakar dilakukan menggunakan metode Morton yang telah dimodifikasi (Morton \& Malone, 1972). Tikus terlebih dahulu dicukur pada daerah punggung sehari sebelum pembuatan luka sekitar $\pm 3 \mathrm{~cm}$. Sebelum dibuat luka tikus diberikan anastesi dengan kombinasi ketamine:xylazine injeksi secara intramuskular dengan perbandingan 10:1 dimana dosis ketamine $10 \mathrm{mg} / \mathrm{KgBB}$ dan xylazine $1 \mathrm{mg} / \mathrm{KgBB}$. Punggung tikus sebelumnya dibersihkan dengan etanol $70 \%$ kemudian dibuat menjadi luka bakar dengan logam berdiameter $\pm 2 \mathrm{~cm}$ yang sudah dipanaskan pada bara api hingga memijar merah, kemudian ditempelkan pada kulit punggung tikus dengan penekanan yang sama selama 7 detik hingga terbentuk luka bakar derajat 2 (Sutrisno et al., 2016).

Setiap kelompok diberikan pengobatan luka sebanyak 2 kali sehari pada waktu pagi dan sore selama 21 hari. Terdapat 5 kelompok perlakuan yang terdiri dari kelompok F1, F2, dan F3 yang diberikan sediaan gel ekstrak daun pucuk merah konsentrasi 2\%, 4\%, dan 6\%, kelompok kontrol positif (Bioplacenton), dan kelompok kontrol negatif (Na-CMC) yang masing-masing terdiri dari 4 ekor tikus. Sediaan dioleskan pada luka secara merata sebanyak $200 \mathrm{mg}$ (yang telah ditara menggunakan spuit) menggunakan batang pengaduk.

Tabel 1. Formula Gel

\begin{tabular}{cccc}
\hline Bahan & $\mathbf{F}_{\mathbf{1}}(\boldsymbol{\%} \mathbf{b} / \mathbf{b})$ & $\mathbf{F}_{\mathbf{2}}(\boldsymbol{\%} \mathbf{b} / \mathbf{b})$ & $\mathbf{F}_{\mathbf{3}}(\boldsymbol{\%} \mathbf{b} / \mathbf{b})$ \\
\hline Ekstrak Daun Pucuk Merah & 2 & 4 & 6 \\
Gliserin & 10 & 10 & 10 \\
Propilenglikol & 5 & 5 & 5 \\
Na-CMC & 3 & 3 & 3 \\
Aquadest ad & 100 & 100 & 100 \\
\hline
\end{tabular}

Sumber: Mappa et al., (2013) 


\section{Pengukuran Diameter Luka Bakar}

Penentuan diameter luka dan persentase penyembuhan luka diamati dengan cara mengukur rata-rata diameter luka yang diukur pada arah vertikal, horizontal, dan kedua diagonal. Diameter luka diukur dengan menggunakan jangka sorong yang dilakukan setiap dua hari sekali untuk masing-masing tikus yang ditentukan berdasarkan bagian tepi ujung terjauh sisi daerah luka (Sutrisno et al., 2016). Pengamatan dilakukan pada hari ke0,3,5,7,9,11,13,15, dan 17 .

\section{HASIL DAN PEMBAHASAN \\ Pembuatan dan Evaluasi Sediaan Gel}

Evaluasi sediaan gel yang dilakukan meliputi uji organoleptik (warna, bentuk, aroma), $\mathrm{pH}$, homogenitas, viskositas, dan daya alir. Hasil evaluasi sediaan gel dapat dilihat pada Tabel 2.

Pengujian homogenitas bertujuan untuk memastikan bahwa sediaan gel dapat dioleskan pada kulit secara merata, dan tidak menggumpal pada saat pengolesan. Pengujian $\mathrm{pH}$ gel bertujuan untuk memastikan bahwa sediaan gel yang dibuat memiliki $\mathrm{pH}$ yang sesuai dengan $\mathrm{pH}$ kulit. Nilai rata-rata $\mathrm{pH}$ sediaan gel formula 1-3 memiliki rentang 4,8-5,7. Hasil ini sesuai dengan persyaratan rentang $\mathrm{pH}$ sediaan topikal yaitu 4,5-6,5 (Latifah, 2007). Nilai
$\mathrm{pH}$ sediaan menjadi lebih kecil dengan peningkatan konsentrasi zat aktif. Hal ini diduga karena adanya kandungan polifenol dalam ekstrak daun pucuk merah. Hasil pengukuran viskositas pada ketiga formula menunjukkan bahwa semakin besar nilai konsentrasi ekstrak maka semakin besar juga nilai viskositasnya, hal ini disebabkan karena sifat ekstrak yang cukup kental dan lengket.

\section{Uji Daya Alir}

Rate of share diperoleh dengan cara membagi nilai shearing stress dengan viskositas sediaan semi solid. Kurva sifat alir yang terbentuk pada ketiga formula menunjukkan sifat aliran plastis tiksotropik. Hal ini terlihat bahwa kurva menurun terdapat di sebelah kiri kurva menaik sehingga kurva terlihat berhimpit (Gambar 1). Tiksotropik terjadi karena proses pemulihan yang lambat dari konsistensi sediaan, contohnya sediaan gel.

Menurut (Martin et al., 1993), sifat alir yang diharapkan dari suatu sediaan setengah padat adalah tiksotropik positif, karena sediaan setengah padat diharapkan mempunyai konsistensi tinggi dalam wadah pada saat penyimpanan, namun saat diberi gaya, dapat dengan mudah dituang dan mudah tersebar.

Tabel 2. Hasil Evaluasi Sediaan Gel

\begin{tabular}{|c|c|c|c|c|}
\hline Organoleptik & $\mathrm{F} 1$ & $\mathrm{~F} 2$ & F3 & Syarat \\
\hline \multicolumn{5}{|l|}{ Organoleptik } \\
\hline Warna & Coklat kemerahan & Coklat kemerahan & Coklat kemerahan & Jernih \\
\hline Bentuk & Setengah padat & Setengah padat & Setengah padat & Setengah padat \\
\hline Aroma & Aromatik lemah & Aromatik lemah & Aromatik lemah & - \\
\hline pH Sediaan & 5,712 & 5,189 & 4,802 & $\begin{array}{l}4,5-6,5 \\
\text { (Tranggono dkk, } \\
\text { 2007) }\end{array}$ \\
\hline Homogenitas & Homogen & Homogen & Homogen & Homogen \\
\hline Viskositas & $479 \mathrm{cP}$ & $565,2 \mathrm{cP}$ & $658,9 \mathrm{cP}$ & - \\
\hline
\end{tabular}


Hasil Pengobatan Luka Bakar pada Hewan Coba

Pengamatan dan Pengukuran Diameter Luka

Pengukuran diameter luka dengan metode modifikasi Morton ini diambil dari berbagai sisi untuk mengetahui penyempitan luka bakar yang lebih akurat. Pengukuran diameter luka bakar dan pengambilan data dilakukan setiap dua hari sekali sampai didapatkan diameter luka sama dengan nol pada hewan coba. Hasil pengukuran diameter luka dapat dilihat pada Tabel 3 dan Gambar 2.

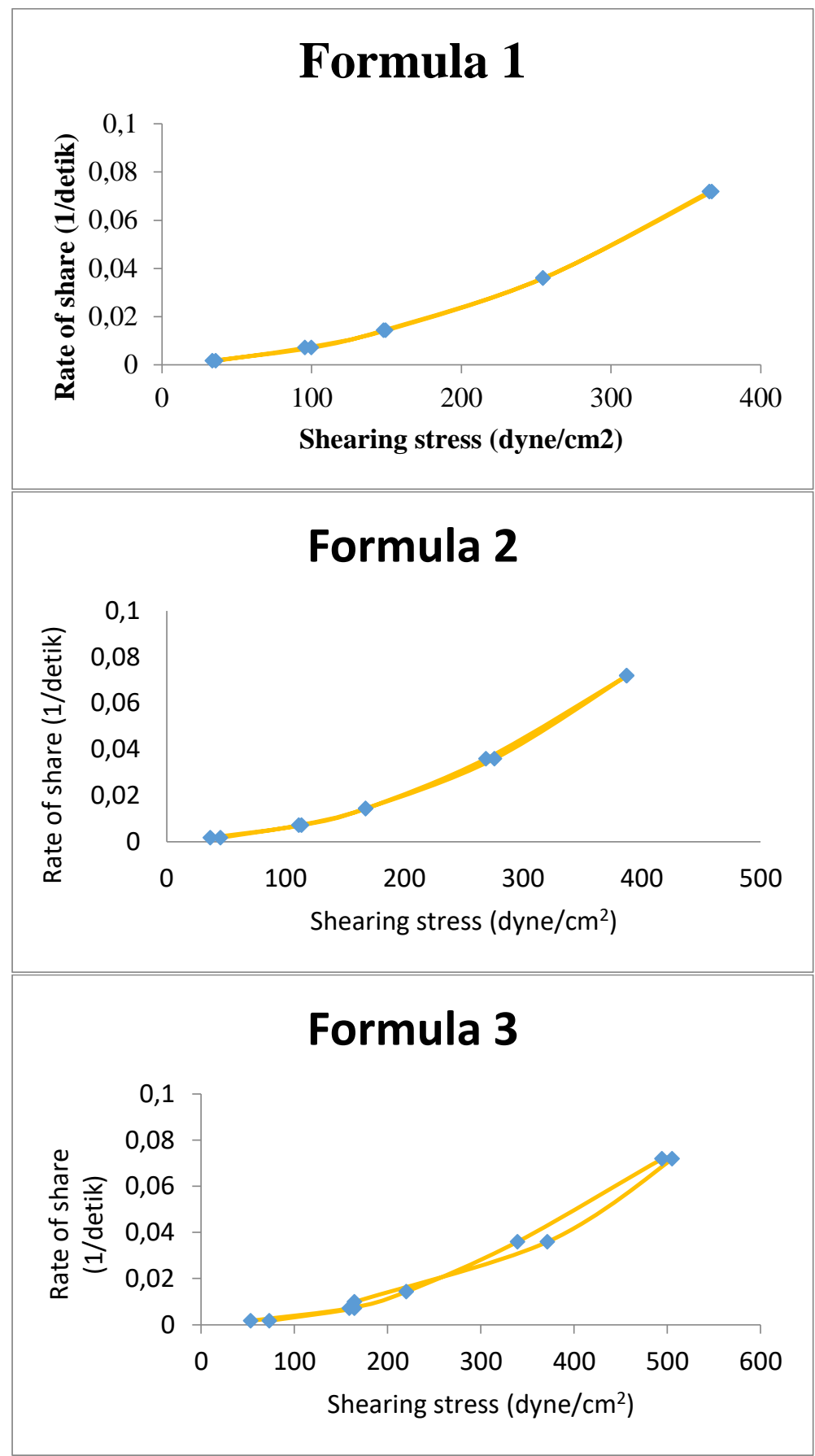

Gambar 1. Rheogram gel 
Tabel 3. Hasil Pengukuran Diameter Luka Bakar

\begin{tabular}{|c|c|c|c|c|c|c|c|c|c|c|}
\hline \multicolumn{11}{|c|}{ Diameter Luka Bakar Hari ke- (cm) } \\
\hline Perlakuan & $\mathbf{0}$ & 3 & 5 & 7 & 9 & 11 & 13 & 15 & 17 & Rata - Rata \\
\hline F1 & $\begin{array}{l}2,00 \\
\pm \\
0,04^{\text {op }}\end{array}$ & $\begin{array}{l}1,94 \pm \\
0,04^{\text {no }}\end{array}$ & $\begin{array}{l}1,89 \pm \\
0,04^{\mathrm{mn}}\end{array}$ & $\begin{array}{l}1,84 \pm \\
0,04^{\mathrm{klm}}\end{array}$ & $\begin{array}{l}1,77 \pm \\
0,02^{\mathrm{jik}}\end{array}$ & $\begin{array}{l}1,71 \pm \\
0,01^{\mathrm{ij}}\end{array}$ & $\begin{array}{l}1,62 \pm \\
0,01^{\mathrm{h}}\end{array}$ & $\begin{array}{l}0,66 \\
\pm \\
0,03^{\mathrm{d}}\end{array}$ & $\begin{array}{l}0,10 \pm \\
0,01^{\mathrm{a}}\end{array}$ & $1,50 \pm 0,66^{\mathrm{c}}$ \\
\hline F2 & $\begin{array}{l}2,14 \\
\pm \\
0,03^{\mathrm{s}}\end{array}$ & $\begin{array}{l}2,08 \pm \\
0,03^{\mathrm{qrs}}\end{array}$ & $\begin{array}{l}2,00 \pm \\
0,02^{\text {opq }}\end{array}$ & $\begin{array}{l}1,96 \pm \\
0,03^{\text {nop }}\end{array}$ & $\begin{array}{l}1,86 \pm \\
0,04^{ \pm m}\end{array}$ & $\begin{array}{l}1,79 \pm \\
0,04^{\mathrm{kl}}\end{array}$ & $\begin{array}{l}1,24 \pm \\
0,04^{\mathrm{f}}\end{array}$ & $\begin{array}{l}0,57 \\
\pm \\
0,04^{\mathrm{c}}\end{array}$ & $\begin{array}{l}0,22 \pm \\
0,01^{\mathrm{b}}\end{array}$ & $1,54 \pm 0,70^{d}$ \\
\hline F3 & $\begin{array}{l}2,12 \\
\pm \\
0,02^{\mathrm{s}}\end{array}$ & $\begin{array}{l}2,03 \pm \\
0,03^{\mathrm{pqr}}\end{array}$ & $\begin{array}{l}1,94 \pm \\
0,02^{\mathrm{no}}\end{array}$ & $\begin{array}{l}1,89 \pm \\
0,02^{\mathrm{mn}}\end{array}$ & $\begin{array}{l}1,79 \pm \\
0,07^{\mathrm{kl}}\end{array}$ & $\begin{array}{l}1,70 \pm \\
0,04^{\mathrm{ij}}\end{array}$ & $\begin{array}{l}1,09 \pm \\
0,10^{\mathrm{e}}\end{array}$ & $\begin{array}{l}0,51 \\
\pm \\
0,02^{\mathrm{c}}\end{array}$ & $\begin{array}{l}0,09 \pm \\
0,01^{\mathrm{a}}\end{array}$ & $1,46 \pm 0,72^{b}$ \\
\hline $\mathrm{K}(+)$ & $\begin{array}{l}2,11 \\
\pm \\
0,10^{\mathrm{s}}\end{array}$ & $\begin{array}{l}1,99 \pm \\
0,11^{\mathrm{op}}\end{array}$ & $\begin{array}{l}1,86 \pm \\
0,05^{ \pm \mathrm{m}}\end{array}$ & $\begin{array}{l}1,77 \pm \\
0,05^{j \mathrm{k}}\end{array}$ & $\begin{array}{l}1,69 \pm \\
0,06^{\mathrm{i}}\end{array}$ & $\begin{array}{l}1,57 \pm \\
0,07^{\mathrm{h}}\end{array}$ & $\begin{array}{l}1,04 \pm \\
0,07^{\mathrm{e}}\end{array}$ & $\begin{array}{l}0,18 \\
\pm \\
0,02^{\mathrm{b}}\end{array}$ & $\begin{array}{l}0,06 \pm \\
0,01^{\mathrm{a}}\end{array}$ & $1.36 \pm 0.76^{\mathrm{a}}$ \\
\hline K (-) & $\begin{array}{l}2,09 \\
\pm \\
0,04^{\mathrm{rs}}\end{array}$ & $\begin{array}{l}2,03 \pm \\
0,02^{\text {pqr }}\end{array}$ & $\begin{array}{l}1,98 \pm \\
0,01^{\mathrm{op}}\end{array}$ & $\begin{array}{l}1,94 \pm \\
0,01^{\text {no }}\end{array}$ & $\begin{array}{l}1,86 \pm \\
0,03^{ \pm m}\end{array}$ & $\begin{array}{l}1,79 \pm \\
0,02^{\mathrm{kl}}\end{array}$ & $\begin{array}{l}1,77 \pm \\
0,08^{\mathrm{ijk}}\end{array}$ & $\begin{array}{l}1,59 \\
\pm \\
0,06^{\mathrm{h}}\end{array}$ & $\begin{array}{l}1,5 \pm \\
0,07^{g}\end{array}$ & $1,84 \pm 0,2^{\mathrm{e}}$ \\
\hline Rata - rata & $\begin{array}{l}2,09 \\
\pm \\
0,05^{\mathrm{i}}\end{array}$ & $\begin{array}{l}2,01 \pm \\
0,05^{\mathrm{h}}\end{array}$ & $\begin{array}{l}1,93 \pm \\
0,06^{\mathrm{g}}\end{array}$ & $\begin{array}{l}1,88 \pm \\
0,07^{\mathrm{f}}\end{array}$ & $\begin{array}{l}1,79 \pm \\
0,06^{\mathrm{e}}\end{array}$ & $\begin{array}{l}1,71 \pm \\
0,08^{\mathrm{d}}\end{array}$ & $\begin{array}{l}1,35 \pm \\
0,32^{\mathrm{c}}\end{array}$ & $\begin{array}{l}0,70 \\
\pm \\
0,52 \\
\text { b }\end{array}$ & $\begin{array}{l}0,39 \pm \\
0,61^{a}\end{array}$ & $1,54 \pm 0,17$ \\
\hline
\end{tabular}

Keterangan : Angka yang diikuti superskrip yang sama menunjukan tidak ada perbedaan nyata antara perlakuan terhadap penyempitan diameter luka bakar pada tikus $\alpha<0.05$ berdasarkan uji lanjut Duncan.

\section{Pengukuran Diameter Luka Bakar}

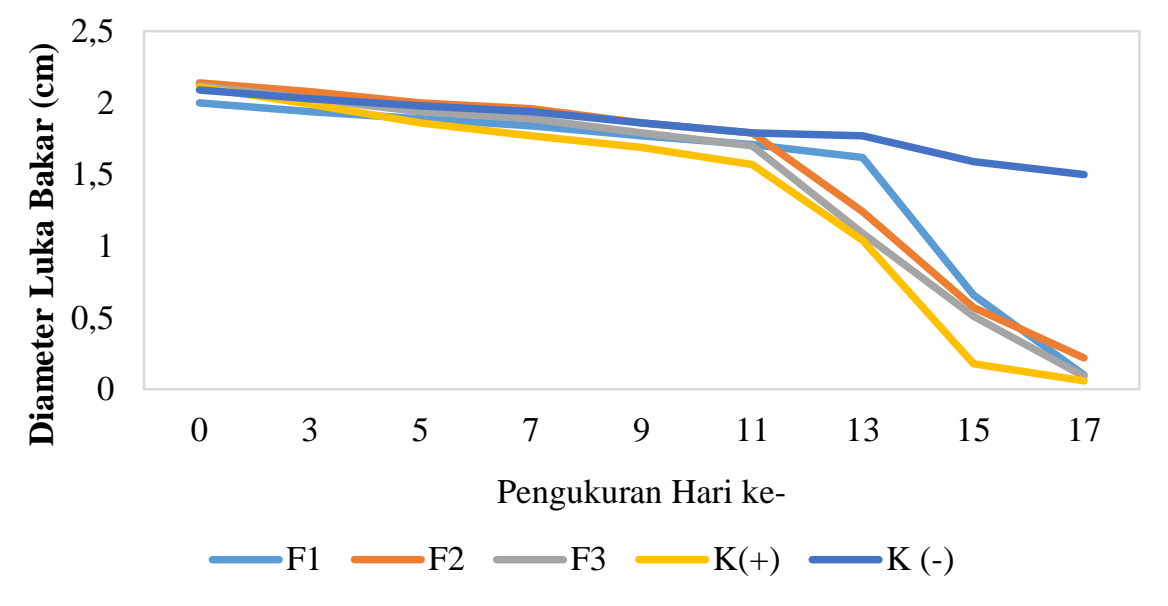

Gambar 2. Pengukuran Diameter Luka Bakar

Berdasarkan uji ANOVA $(\alpha 0,05)$, semua perlakuan baik itu formula 1, 2, dan 3 menunjukkan rata-rata diameter luka yang berbeda nyata dengan kontrol negatif, artinya semua formula mempunyai aktivitas untuk menyembuhkan luka bakar. Sedangkan formula terbaik yang mendekati kontrol positif yaitu formula 3 dengan konsentrasi ekstrak tertinggi (6\%). Untuk mengetahui adanya perbedaan pada masingmasing kelompok perlakuan, maka dilanjutkan dengan uji Duncan.
Hasil uji lanjut Duncan pada faktor formula menunjukkan bahwa masingmasing perlakuan memberikan pengaruh yang berbeda terhadap penurunan diameter luka bakar. Hasil uji lanjut pada faktor hari menunjukkan bahwa setiap hari pengukuran memiliki pengaruh yang berbeda terhadap penurunan diameter luka bakar. Penyembuhan luka bakar paling baik terjadi pada hari ke-17. Hasil uji lanjut interaksi antar formula, lama pemberian menunjukkan bahwa formula 3 pada hari 
ke-17, dan formula 1 pada hari ke-17 memberikan pengaruh yang sama dengan kontrol positif pada hari ke-17 dan memberikan pengaruh yang berbeda dengan yang lainnya.

\section{Persentase Penyembuhan Luka Bakar}

Tabel 4 dan Gambar 3 menunjukkan bahwa formula 3 memiliki persentase penyembuhan luka bakar paling baik yaitu 99,81\% dan hampir memiliki efek yang sama dengan kontrol positif yaitu 99,91\%. Formula 2 dan 3 memiliki efektivitas penyembuhan pada luka bakar dengan persentase penyembuhan 99,75\%, 98,94\%, sedangkan kontrol negatif memiliki persentase penyembuhan hanya $48,49 \%$.

Hasil tersebut menunjukkan bahwa kelompok perlakuan 1,2 , dan 3 efektif terhadap penyembuhan luka bakar dan formula 3 paling efektif karena mendekati kontrol positif. Sedangkan kontrol negatif berbeda nyata dengan semua kelompok perlakuan, karena hanya diberikan basis gel.

\section{Perkembangan Penyembuhan Luka Bakar}

Proses penyembuhan luka bakar diawali dengan fase inflamasi, segera setelah luka terjadi dan berakhir 3 hari, tanpa adanya inflamasi tidak akan terjadi proses penyembuhan luka, luka akan tetap menjadi sumber nyeri sehingga proses inflamasi dan penyembuhan luka akan cenderung menimbulkan nyeri (Izzati, 2015). Pada fase inflamasi terjadi peningkatan permeabilitas membran sel sehingga pada fase ini akan terdapat peradangan, kemerahan, dan nyeri. Perubahan diameter luka juga menjadi indikator proses penyembuhan luka bakar.

Pada fase inflamasi senyawa aktif yang berperan yaitu flavonoid, karena flavonoid berfungsi untuk mengurangi peradangan pada luka bakar. Flavonoid bekerja mengurangi pembengkakan dengan mekanisme penangkapan radikal bebas dan penghambatan enzim siklooksigenase sehingga prostaglandin menjadi terhambat (Selawa \& Max Revolta John Runtuwene, 2013). Pada fase inflamasi terjadi peristiwa homeostasis (penghentian pendarahan), dibantu oleh benang-benang fibrin yang saling bertautan sehingga sel-sel darah merah beserta plasma akan terjaring dan membentuk gumpalan. Gambaran luka pada hari ke-0 hingga ke-17 dapat dilihat pada Tabel 5 .

Pada hari ke-3 gumpalan ini akan membentuk keropeng, terbentuknya keropeng merupakan awal dari penyembuhan luka dan senyawa aktif yang berperan yaitu tanin sebagai astringen yang menyebabkan penciutan pori-pori kulit, memperkeras kulit (Handayani \& Sentat, 2016). Diameter luka belum mengalami penurunan yang signifikan pada hari ke-3.

Tabel 4. Persentase Penyembuhan Luka Bakar

\begin{tabular}{llllllllll}
\hline Perlakuan & \multicolumn{8}{c}{ Persentase Penyembuhan Luka Bakar Hari ke- (\%) } \\
\cline { 2 - 10 } & 0 & 3 & 5 & 7 & 9 & 11 & 13 & 15 & 17 \\
\hline Formula 1 & 0 & 5,91 & 10,69 & 15,36 & 21,67 & 26,89 & 34,39 & 89,11 & 99,75 \\
Formula 2 & 0 & 5,52 & 12,65 & 16,11 & 24,45 & 30,03 & 66,42 & 92,90 & 98,94 \\
Formula 3 & 0 & 8,31 & 16,26 & 20,52 & 28,70 & 35,69 & 73,56 & 94,21 & 99,81 \\
Kontrol Positif & 0 & 11,05 & 22,29 & 29,63 & 35,84 & 44,63 & 75,70 & 99,27 & 99,91 \\
Kontrol Negatif & 0 & 5,65 & 10,24 & 13,83 & 20,79 & 26,64 & 28,27 & 42,12 & 48,49 \\
\hline
\end{tabular}

Tabel 5. Perkembangan Penyembuhan Luka Bakar

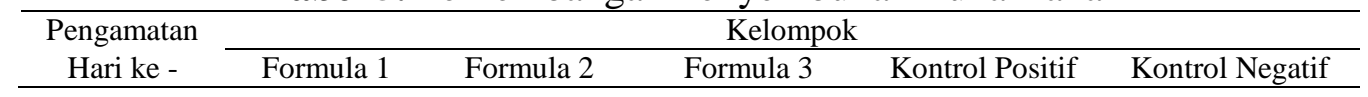




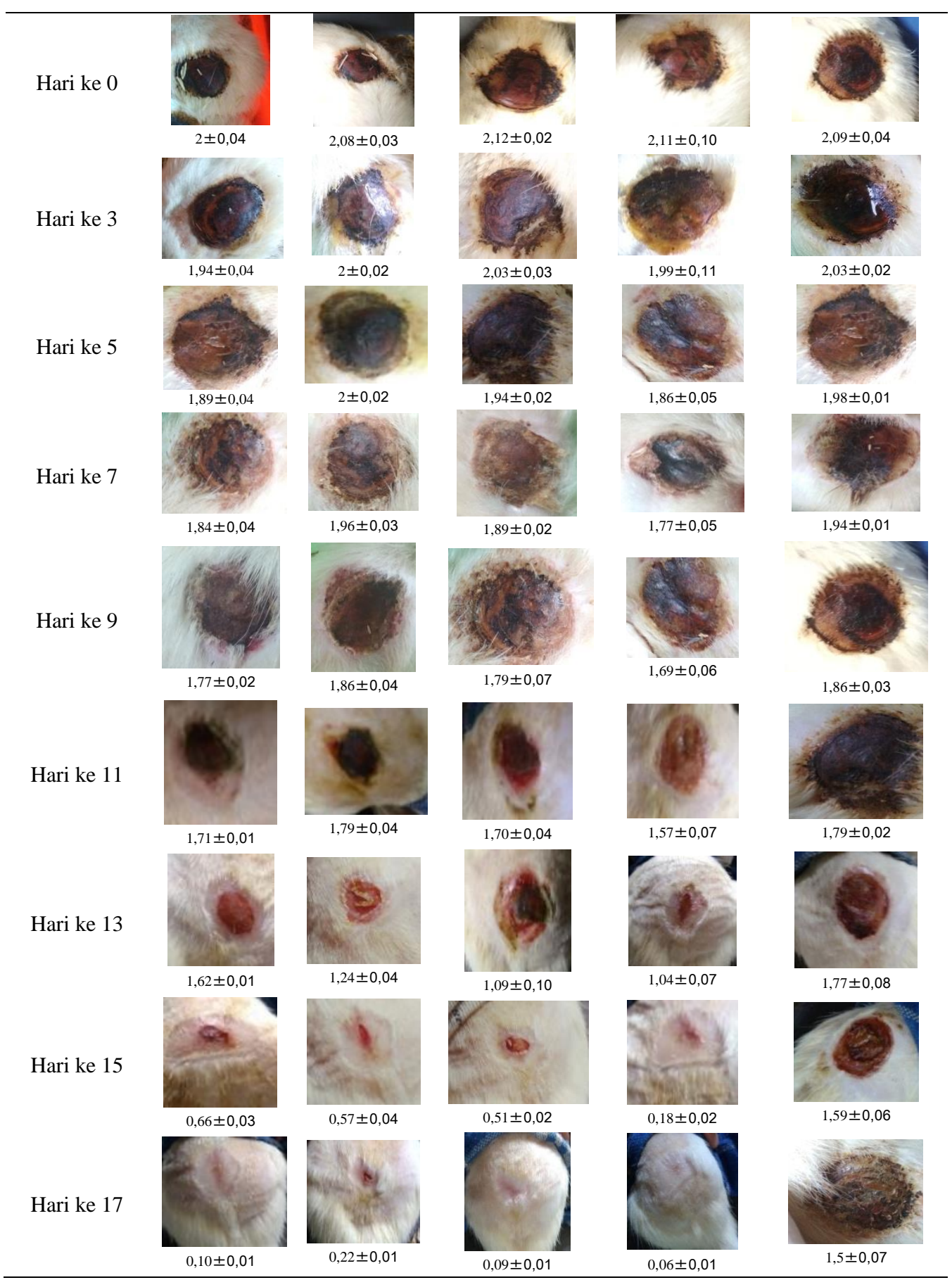

Selanjutnya adalah fase proliferasi, dimana pada fase ini luka dipenuhi dengan fibroplasia dan kolagen membentuk jaringan berwarna kemerahan dengan permukaan halus, fase ini terjadi pada hari ke-11 dimana keropeng terlepas dan terbentuk jaringan berwarna kemerahan. Diameter luka berkurang secara bermakna setelah hari ke11 (Gambar 3). Senyawa yang berperan yaitu flavonoid, dengan menghambat sekresi

enzim lisosom yang merupakan mediator inflamasi. Penghambatan mediator inflamasi ini dapat menghambat proliferasi dari proses radang (Ulviani et al., 2016).

Fase akhir dari proses penyembuhan luka yaitu fase maturasi atau remodeling, dimana terjadi proses yang dinamis berupa kontraksi luka dan pematangan parut dan selama fase ini jaringan baru akan disusun sedemikian rupa seperti jaringan asalnya dan 
luka sembuh ditandai dengan jaringan kembali seperti semula dan adanya pertumbuhan kembali bulu tikus (Izzati, 2015). Pada kelompok kontrol negatif, tidak terjadi penyembuhan luka, karena hanya diberikan basis gel sehingga luka bakar pada kontrol negatif membutuhkan waktu yang cukup lama dalam setiap fase penyembuhannya.

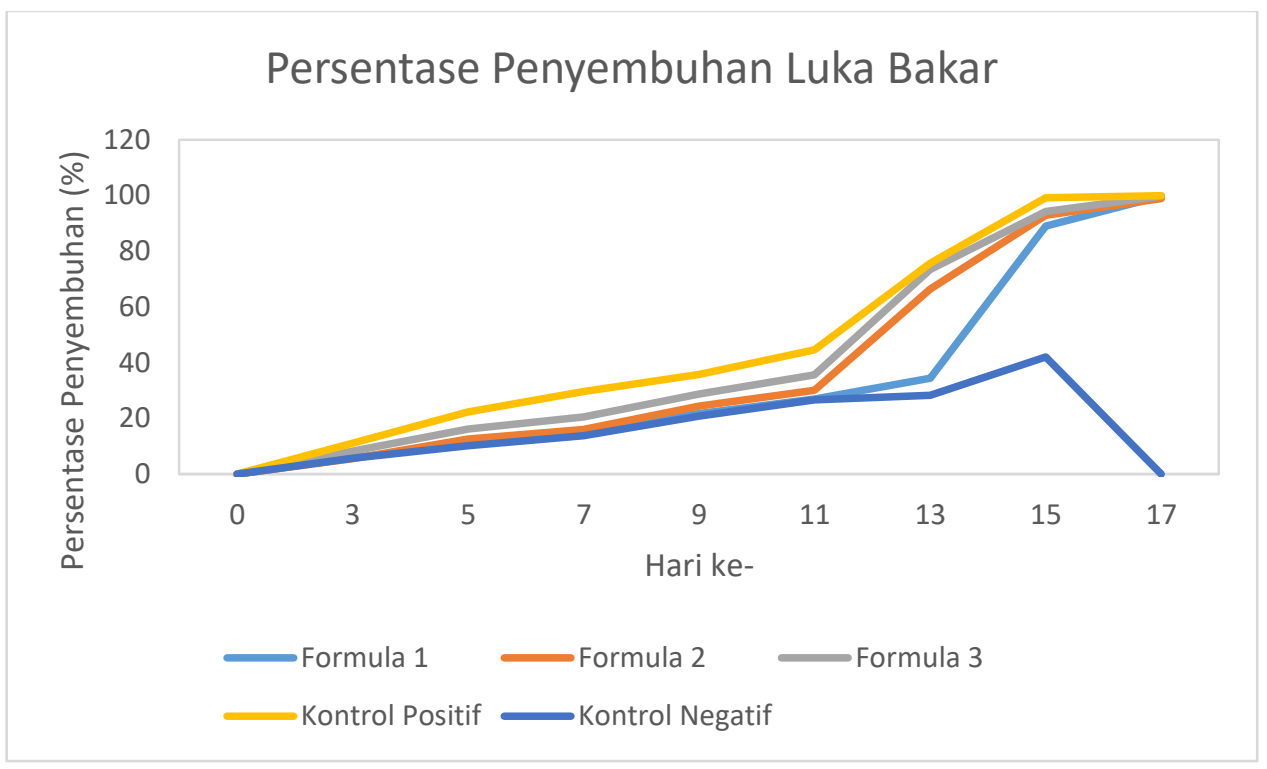

Gambar 3. Persentase Penyembuhan Luka Bakar

\section{KESIMPULAN}

Gel ekstrak daun pucuk merah memiliki aktivitas penyembuhan luka bakar dimana gel formula 3 dengan ekstrak daun pucuk merah 6\% paling efektif untuk penyembuhan luka bakar setelah 17 hari.

\section{DAFTAR PUSTAKA}

DeLaune, S. C., \& Ladner, P. K. (2002). Fundamentals of Nursing: Standards \& Practice. Delmar Thomson Learning. https://books.google.co.id/books?id= Y4Cxe9jSR10C

DepKes. (2001). Materia Medika Indonesia (V). BPOM.

Handayani, F., \& Sentat, T. (2016). Uji Aktivitas Ekstrak Etanol Daun Kersen (Muntingia calabura L.,) Terhadap Penyembuhan Luka Bakar Pada Kulit Mencit Putih Jantan (Mus musculus). Jurnal Ilmiah Ibnu Sina, 1(2), 131-142.

Haryati, N. A., Saleh, C., \& -, E. (2016).
Uji Toksisitas Dan Aktivitas Antibakteri Ekstrak Daun Merah Tanaman Pucuk Merah (Syzygium myrtifolium Walp.) Terhadap Bakteri Staphylococcus aureus dan Escherichia coli. JURNAL KIMIA MULAWARMAN, 13(1), 35-40. http://jurnal.kimia.fmipa.unmul.ac.id /index.php/JKM/article/view/43

Hasyim, N., Pare, K. L., \& Kurniati, A. (2012). Formulasi Dan Uji Efektivitas Gel Luka Bakar Ekstrak Daun Cocor Bebek (Kalanchoe pinnata L.) Pada KelincI (Oryctolagus cuniculus). MAJALAH FARMASI DAN FARMAKOLOGI, 16(2), 89-94. http://journal.unhas.ac.id/index.php/ mfdf/article/view/468

Izzati, U. Z. (2015). Efektivitas Penyembuhan Luka Bakar Salep Ekstrak Etanol Daun Senggani (Melastoma malabathricum L.) Pada Tikus (Rattus norvegicus) Jantan 
Galur Wistar. Jurnal Mahasiswa Farmasi Fakultas Kedokteran UNTAN, 3(1). http://jurnal.untan.ac.id/index.php/j mfarmasi/article/view/11025/10497

Latifah, R. I. T. F. (2007). Buku Pegangan Ilmu Pengetahuan Kosmetik. Media Pusindo.

Mappa, T., Edy, H. J., \& Kojong, N. (2013). Formulasi Gel Ekstrak Daun Sasaladahan (Peperomia pellucida (L.) H.B.K) dan Uji Efektivitasnya Terhadap Luka Bakar Pada Kelinci (Oryctolagus Cuniculus). PHARMACON; Vol 2, No 2 (2013): Pharmacon.

https://doi.org/10.35799/pha.2.2013. 1606

Martin, A., James, S., \& Cammarata, A. (1993). Farmasi Fisik Jilid II (Joshita (ed.)). UI Press.

Maswadeh, H. M., Semreen, M. H., \& Naddaf, A. R. (2006). Antiinflammatory activity of Achillea and Ruscus topical gel on carrageenan-induced paw edema in rats. Acta Poloniae Pharmaceutica, 63(4), 277-280.

Moerfiah, Indriani, L., \& Pramayudha, R. (2019). Utilizing of $96 \%$ Etanol Extract Activity Red Leaf ( Syzygium myrtifolium Walp .) Maseration and Socletation Method as an Antidiarrhea at Male Mice. International Journal of Recent Technology and Engineering, 8(2), 260-263.
https://doi.org/10.35940/ijrte.B1045. 0782S719

Morton, J. J., \& Malone, M. H. (1972). Evaluation of vulneray activity by an open wound procedure in rats. Archives Internationales de Pharmacodynamie et de Therapie, 196(1), 117-126.

Selawa, W., \& Max Revolta John Runtuwene, G. C. (2013). Kandungan Flavonoid Dan Kapasitas Antioksidan Total Ekstrak Etanol Daun Binahong (Anredera cordifolia ( Ten .) Steenis). PHARMACON Jurnal Ilmiah Farmasi, 2(1), 18-22.

Sutrisno, E., Adnyana, I. K., Sukandar, E., Fidrianny, I., \& Aligita, W. (2016). Anti-inflammatory study of Anredera cordifolia leaves and Centella asiatica herbs and its combinations using human red blood cell-membrane stabilization method. Asian Journal of Pharmaceutical and Clinical Research, 9, 78-80. https://doi.org/10.22159/ajpcr.2016. v9i5.11973

Ulviani, F., Yusriadi, Y., \& Khaerati, K. (2016). Pengaruh Gel Ekstrak Daun Sirih Merah (Piper crocatum Ruiz \& Pav) Terhadap Penyembuhan Luka Bakar Pada Kelinci (Oryctolagus cuniculus). Jurnal Farmasi Galenika (Galenika Journal of Pharmacy), 2(2), 103-110. https://doi.org/https://doi.org/10.224 87/j24428744.2016.v2.i2.5977 